\title{
ANATOMIJA POSLOVNOG USPJEHA I RAZVOJA PODUZEĆA S OSVRTOM NA KLJUČNE UPRAVLJAČKE ODLUKE
}

\author{
Mr. sc. Anđelko Kaščel \\ Laser Inženjering d.o.o. za proizvodnju i usluge \\ Sisačka cesta 11, 10000 Zagreb, Hrvatska \\ Telefon: 0914222179, e-mail: andelko.kascel@laser-ing.com
}

\section{SAŽETAK}

Temeljne zadaće menadžmenta u tržišnom gospodarstvu su osigurati optimalno poslovanje i ostvarivanje dobiti te postići vremensku neograničenost poslovanja izraženu kroz budući rast i razvoj poduzeća. Za to je nužno organizirati poslovni sustav kojim će se pravovremeno identificirati rizici koji mogu utjecati na poslovanje poduzeća i donošenje poslovnih odluka. Iznimno je važno pažnju posvetiti analizi poslovanja i razvoju sustava upravljanja rizicima primjerenim tržišnim i društvenim promjenama. Ovaj je rad posvećen anatomiji poslovnog uspjeha i razvoja odabranog poduzeća od njegova osnutka 2014. godine do sadašnjeg vremena, zaključno s 2020. godinom. Navedeno sedmogodišnje razdoblje, pored stalnih tržišnih izazova, posebno je obilježilo vrijeme globalne gospodarske recesije i najnovija pojava globalne pandemije uzrokovane virusom COVID-19, a koja je značajno utjecala na promjene ukupnog društvenog i gospodarskog života u svijetu i u našoj zemlji. Općenito promatrano, te su pojave imale negativan utjecaj na ekonomiju izraženu povećanjem nezaposlenosti, smanjenjem prihoda, potražnje i proizvodnje, rastom cijena i tržišnom neizvjesnosti, posebno u segmentu malih poduzeća. Također, uobičajena je poduzetnička pretpostavka da su u poslovnom i razvojnom ciklusu poduzeća ključne prva, treća i sedma godina poslovanja, svaka sa svojim specifičnostima koje nose tržišni, ekonomsko politički, ali i upravljački rizici. U takvom gospodarskom okruženju poslovalo je odabrano poduzeće, a njegov menadžment donosio poslovne odluke kojima je upravljao poslovnim rizicima $i$ razvojnim planovima. Zato je ovaj rad posvećen istraživanju poslovanja i razvoja odabranog malog poduzeća iz segmenta uslužne metaloprerađivačke djelatnosti i upravljačkim odlukama kojima su osigurani njegovo poslovanje, razvoj i rast. Analizirano je njegovo poslovanje kroz sedmogodišnje razdoblje korištenjem financijskih i nefinancijskih podataka i informacija u navedenom vremenskom periodu. Istraživanju se pristupilo s aspekta analiziranja vanjskih i unutarnjih čimbenika poslovanja te ključnih upravljačkih odluka menadžmenta. Problem istraživanja bio je prepoznati rizike koji su utjecali na mogućnost njegova poslovanja i razvoja. Cilj istraživanja jest identificirati ključne upravljačke odluke i modele upravljanja navedenim rizicima u danim tržišnim uvjetima. Pažnja je također posvećena i poslovnoj filozofiji menadžmenta, koja uz opće upravljačke principe sadrži $i$ specifičnu upravljačku filozofiju i principe.

Ključne riječi: anatomija poslovnog uspjeha, vremenska neograničenost poslovanja, rizici poslovanja, ključne upravljačke odluke, specifična upravljačka filozofija 


\section{UVOD}

Poduzeće je poslovno-financijski sustav u kojem menadžeri svojim odlukama usmjeravaju poslovanje željenom cilju, koji podrazumijevaju optimalno poslovanje, ostvarivanje dobiti te vremenska neograničenost poslovanja. Njihove se odluke mogu kategorizirati kao odluke o poslovanju usmjerene na politiku prihoda i rashoda, investicijske odluke usmjerene na pribavljanje i alokaciju sredstava ulaganja te odluke o financiranju usmjerene na politiku korištenja rezultata poslovanja i raspodjele dobiti na dio koji će se reinvestirati, odnosno dio koji će vlasnici preuzeti kao naknadu za rizike ulaganja u poslovni projekt. Navedene okvirne napomene upućuju nas na teorijski koncept promišljanja poduzetništva, što nije zadaća ovog rada. Primarno, ovaj rad je posvećen prikazu konkretnog poslovnog projekta koji je postavljen i razvijao se u vremenu koje u neposrednoj prošlosti karakteriziraju opća gospodarska kriza i recesija, a u novije vrijeme kriza globalne pandemije izazvane bolešću COVID-19. Pored standardnih problema poslovanja u globalnom tržišnom okruženju, te su pojave dodatno utjecale na promjene društvenog i gospodarskog života i običaja, kako u svijetu tako i u našoj zemlji. Zbog toga je ovaj rad posvećen istraživanju poslovanja jednog poduzeća od osnivanja do sadašnjih dana i poslovnim odlukama njegova menadžmenta kojima je ono, s više ili manje uspješnosti, vođeno u proteklom sedmogodišnjem razdoblju poslovanja, s naglaskom na razdoblje poslovanja za vrijeme globalne pandemije. Istraživanju se pristupilo s tri aspekta, prvo s aspekta makro okruženja u kojem se posluje na domaćem tržištu s kritičkim osvrtom na ograničenja tog okruženja, potom s aspekta poslovnih odluka menadžmenta kojima je vođeno i usmjeravano poslovanje, naročito onih u kriznim razdobljima, te naposljetku s aspekta poslovne filozofije uprave kojom se tumače uspješni rezultati poslovanja. Problem istraživanja bio je prepoznati rizike u trenucima negativnih utjecaja vanjskog okruženja i mogućnosti njihova rješavanja. Cilj istraživanja jest utvrditi i analizirati ključne upravljačke odluke i modele upravljanja rizicima poslovanja u danim tržišnim uvjetima. Temeljna hipoteza rada jest da se analizom i interpretacijom podataka dobivenih analizom financijskih izvještaja mogu identificirati i procijeniti kvaliteta upravljačkih odluka i njihov doprinos rezultatima poslovanja. Primarno istraživanje obuhvaća analizu financijskih izvještaja odabranog poduzeća, dok sekundarno istraživanje podrazumijeva korištenje relevantne stručne literature. Metode rada obuhvaćaju primjenu analitičkih metoda i tehnika, a dobiveni rezultati kritički osvrt na upravljačke odluke.

\section{PRIKAZ ODABRANOG PODUZEĆA}

Anatomija poslovnog uspjeha i razvoja poduzeća provodi se istraživanjem poslovanja odabranog poduzeća metaloprerađivačke djelatnosti. Poduzeće je osnovano 2014. godine i od osnutka do današnjih dana, unatoč brojnim kriznim uvjetima poslovanja koji svoj vrhunac doživljavaju pojavom globalne pandemije, posluje pozitivno i bilježi neprekidan rast i jačanje financijskog stanja i rezultata poslovanja. Djelatnost poduzeća je široko postavljena, ali temeljnu djelatnost predstavljaju laserska obrada i dorada metala, proizvodnja proizvoda od metala, proizvodnja metalnih konstrukcija i njihovih dijelova, dok se među ostalim djelatnostima ističu kupnja i prodaja robe, zastupanja inozemnih tvrtki, prijevoz za vlastite i tuđe potrebe u domaćem i inozemnom prometu i dr. Poduzećem upravlja jedini vlasnik kao glavni menadžer, s tim da su u određenim kraćim vremenskim razdobljima poslove 
glavnog menadžera obavljale i druge osobe. Presudno za pokretanje vlastitog biznisa u ovom poduzeću bilo je veliko poslovno iskustvo u zemlji i inozemstvu te dobro poznavanje tržišta metaloprerađivačke djelatnosti. Razvojni put poduzeće započinje skromnim vlastitim ulaganjima vlasnika i proizvodnjom organiziranom u unajmljenom prostoru, a potom se dodatnim ulaganjima poticajnih sredstava HBOR-a i kreditima poslovnih banaka postupno razvija te koristeći suvremenu proizvodnu tehnologiju povećava kapacitete i tržišni udio na domaćem i inozemnom tržištu. Proizvodni i tržišni razvoj ravnomjerno prati jačanje financijskog stanja i rezultate poslovanja tvrtke kroz sve godine poslovanja. Također, s rastom proizvodnje i prometa, raste i broj zaposlenika od početna 4 u prvoj godini poslovanja do 43 zaposlenika u 2020. godini, što je zahtijevalo i adekvatnu organizaciju rada. Važno je napomenuti da se pri svakom novom razvojnom koraku, osim vlastitog znanja i iskustva, koriste znanja i iskustva vrhunskih konzultanata iz zemlje i inozemstva. Posebno se razvija i vlastiti istraživački i projektni centar za kreiranje novih proizvoda i usluga za vlastite potrebe i potrebe vanjskih korisnika. U trenutku pisanja ovog rada poduzeće je pustilo u rad najsuvremeniji laserski stroj za rezanje i obradu metala, koji omogućuje obavljanje i najsloženijih proizvodnih operacija, kao i niz novih proizvodnih usluga vrlo traženih na domaćem i inozemnom tržištu. Očekuje se da će to ubrzati ostvarivanje budućih planova i ciljeva te misije i vizije poduzeća.

\section{MISIJA I VIZIJA}

Misija poduzeća jest, koristeći inovativne tehnologije i motivirane zaposlenike, pružiti vrhunske usluge i inovativna rješenja rezanja i strojne obrade metala za domaće i međunarodne kupce te pritom primjenjivati visoke poslovne i ekološke standarde te radnu etiku, što može dovesti do dodane vrijednosti.

Vizija poduzeća jest postati vodeći regionalni inovativni servisni centar za usluge rezanja i strojnu obradu metala.

Slika 1. Prihodi 2014. - 2020. i plan poslovanja 2021.

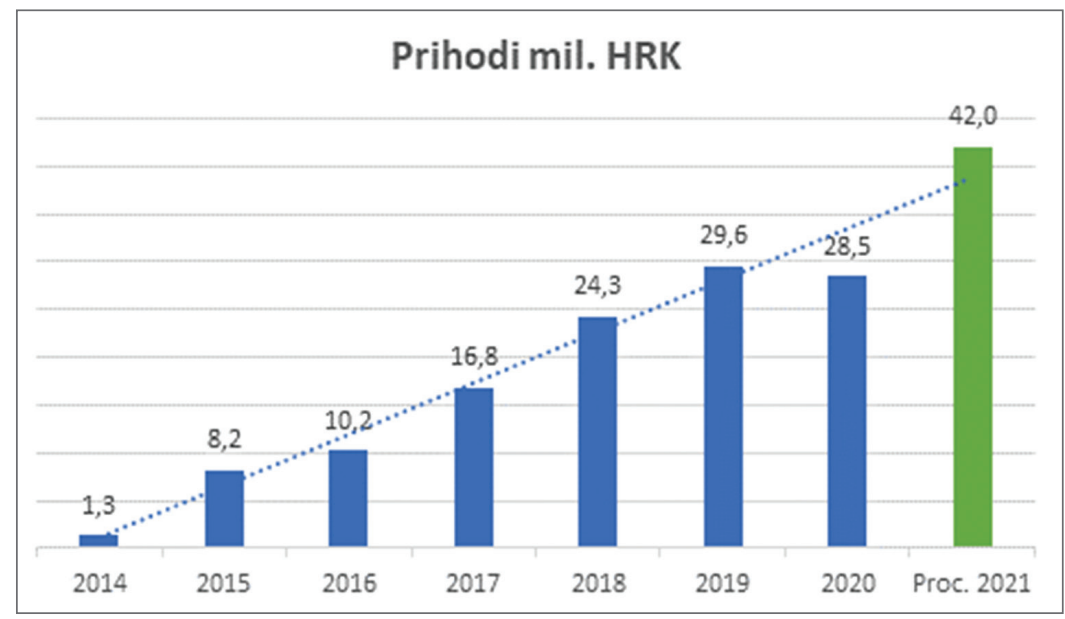

Izvor: Rad autora 
Slika 1. prikazuje kretanje ukupnih prihoda poduzeća u promatranom sedmogodišnjem razdoblju poslovanja poduzeća. Vidljivo je da se na tragu ostvarivanja vizije poduzeća tijekom promatranog razdoblja sustavno pravolinijski povećavaju ukupni prihodi poduzeća. Izuzetak čini kretanje ukupnih prihoda u pandemijskoj godini poslovanja, kada je došlo do manje stagnacije i pada prihoda u odnosu na prethodnu godinu poslovanja i prosječan rast po godinama poslovanja. Tijekom ukupnog razdoblja sustavno se povećavaju prihodi poduzeća. Međutim, planiranim prihodima u tekućoj godini poslovanja namjerava se nadoknaditi navedeni pad prihoda u pandemijskoj godini poslovanja i osigurati dodatni rast u tekućoj 2021. godini. U trenutku pisanja ovog rada, prema ostvarenim prihodima za prvih šest mjeseci tekuće godine, očekuje se da će realni godišnji rast prihoda premašiti planirani okvir rasta.

\section{IZVORI FINANCIJSKIH INFORMACIJA}

Da bi se osiguralo pravodobno i kvalitetno odlučivanje menadžera u vođenju poduzeća, potrebne su različite informacije, posebice financijske informacije o rezultatima poslovanja, koje pomažu u donošenju poslovnih odluka. Izvori tih informacija su temeljni financijski izvještaji koji javnosti pružaju podatke o rezultatima poslovanja poduzetnika. „Financijski izvještaji služe kao kontrolna ploča s mjernim instrumentima. Oni izvještavaju o radu menadžera, potvrđuju njihove uspjehe i neuspjehe i upozoravaju na probleme“ (Meigs \& Meigs, 1999, str. 923). Za potrebe ovog rada korišteni su temeljni financijski izvještaji odabranog poduzeća i to Bilanca i Račun dobiti i gubitka za sedmogodišnje razdoblje poslovanja poduzetnika. To su dva temeljna financijska izvještaja jer sadrže prikaz financijskog stanja i poslovanja poduzetnika u određenom razdoblju poslovanja. „Promatrani zajedno, govore o „zdravstvenom stanju“ nekog poduzeća, a utvrditi i razumjeti to „stanje“ znači imati mogućnost donositi primjerene i racionalne poslovne odluke" (Grupa autora, redaktor Lajoš, Ž., 2008, str. 52).

\subsection{Bilanca}

Bilanca pokazuje financijsko stanje poduzetnika na određeni dan. Sadržajno ona obuhvaća imovinu i izvore te imovine redovito na kraju poslovne godine, pri čemu je s jedne strane imovina sadržana u aktivi bilance, a nasuprot tome su kapital i obveze sadržani u pasivi bilance, kao izvori raspoložive imovine u aktivi bilance. $U$ aktivi bilance dugotrajna imovina je podijeljena na nematerijalnu, materijalnu, financijsku imovinu i potraživanja, a kratkotrajna imovina je podijeljena na zalihe, potraživanja, kratkotrajnu financijsku imovinu i novac. Tako klasificirane skupine dalje se raščlanjuju na podskupine po vrstama imovine. U pasivi bilance izvori imovine podijeljeni su na kapital kao vlastiti izvor imovine te na obveze, dugoročne i kratkoročne, kao tuđi izvori angažirane imovine. „Može se zaključiti da bilanca predstavlja osnovnu podlogu za analizu financijskog položaja, za utvrđivanje slabosti i nedostataka u poslovanju te za predviđanje budućeg poslovanja. U razmatranju tog položaja, posebno značajnu ulogu imaju veze i međuodnosi koji postoje između osnovnih elementa bilance. Pri tome je osobito važna struktura imovine, obveza i kapitala, kao i međusobna povezanost i uvjetovanost pojedinih dijelova imovine i izvora imovine" (Grupa autora, redaktor Lajoš, Ž., 2008. str. 54). Temeljna značajka bilance jest bilančna 
ravnoteža aktive i pasive. Svojim sadržajem bilanca sama po sebi ne govori mnogo o financijskom stanju poduzetnika pa se tek izučavanjem njezine strukture stječe uvid u kvalitetu bilance, odnosno financijskog stanja poduzetnika. Prikaz bilance poduzeća kroz protekle godine poslovanja daje se u nastavku.

Tablica 1. Bilanca poduzeća 2014-2020.

\begin{tabular}{|c|c|c|c|c|c|c|c|}
\hline \multirow{2}{*}{ OPIS } & \multicolumn{7}{|c|}{ Godina } \\
\hline & 2014. & 2015. & 2016. & 2017. & 2018. & 2019. & 2020. \\
\hline 1. Dugotrajna imovina & 68.787 & 52.710 & 263.868 & 3.078 .864 & 9.556 .500 & 14.086 .589 & 14.064.418 \\
\hline - Nematerijalna & 68.787 & 0 & 0 & 0 & 889.538 & 1.065 .058 & 1.863 .225 \\
\hline - Materijalna & 0 & 52.710 & 263.868 & 3.078 .864 & 5.248 .093 & 12.985 .472 & 12.201 .193 \\
\hline - Financijska & 0 & 0 & 0 & 0 & 3.618 .869 & 36.061 & 0 \\
\hline - Potraživanja & 0 & 0 & 0 & 0 & 0 & 0 & 0 \\
\hline 2. Kratkotrajna imovina & 960.882 & 1.931 .553 & 3.178 .874 & 5.474 .764 & 5.721 .667 & 6.524 .324 & 9.461 .574 \\
\hline 2.1. Zalihe & 67.461 & 146.617 & 594.875 & 661.636 & 1.231 .268 & 1.788 .755 & 2.422 .824 \\
\hline 2.2. Potraživanja & 767.077 & 1.342 .200 & 1.997 .654 & 3.752 .587 & 4.112 .920 & 4.357.374 & 5.610 .895 \\
\hline 2.3. Financijska & 60.500 & 137.417 & 28.345 & 883.570 & 32.200 & 32.668 & 481.828 \\
\hline 2.4. Novac & 75.844 & 164.146 & 558.000 & 176.971 & 295.279 & 345.527 & 946.027 \\
\hline UKUPNO AKTIVA & 1.029 .669 & 1.984 .263 & 3.442 .742 & 8.553 .628 & 15.278.167 & 20.610 .913 & 23.525.992 \\
\hline 3. Kapital i rezerve & 21.270 & 340.747 & 536.828 & 931.120 & 1.343 .093 & 6.036 .473 & 6.068 .035 \\
\hline 3.1. Upisani & 20.000 & 20.000 & 20.000 & 20.000 & 20.000 & 1.170 .700 & 1.170 .700 \\
\hline 3.2. Kapitalne rezerve & 0 & 0 & 0 & 0 & 0 & 2.264 .101 & 1.681 .152 \\
\hline 3.3. Zadržana dobit & 0 & 1.270 & 278.089 & 536.436 & 911.120 & 2.130 .546 & 2.633 .660 \\
\hline 3.4. Dobit / gubitak godine & 1.270 & 319.477 & 258.739 & 374.684 & 411.973 & 471.126 & 582.523 \\
\hline 4. Rezerviranja & 0 & 147.000 & 147.000 & 337.615 & 476.724 & 0 & 679.726 \\
\hline 5. Dugoročne obveze & 0 & 0 & 0 & 3.070 .029 & 9.619 .781 & 10.933 .486 & 12.461.591 \\
\hline 6. Kratkoročne obveze & 1.008.399 & 1.495 .502 & 2.738.914 & 4.208 .864 & 3.785 .014 & 3.640 .954 & 4.316 .640 \\
\hline 6.1. Dobavljači & 976.706 & 1.285 .265 & 2.497 .968 & 3.757.749 & 3.390 .805 & 3.131 .403 & 3.848 .412 \\
\hline 6.2. Zaposlenici & 23.025 & 84.438 & 88.864 & 239.608 & 194.495 & 194.574 & 267.340 \\
\hline 6.3. Porezi i doprinosi & 6.690 & 111.513 & 65.406 & 175.263 & 117.196 & 185.520 & 200.888 \\
\hline 6.4. Ostalo & 1.978 & 15.300 & 86.676 & 42.244 & 136.037 & 129.457 & 0 \\
\hline UKUPNO PASIVA & 1.029 .669 & 1.984 .263 & 3.442 .742 & 8.553 .628 & 15.278.167 & 20.610 .913 & 23.525.992 \\
\hline
\end{tabular}

Izvor: Rad autora

\subsection{Račun dobiti i gubitka}

Glavni ciljevi poslovanja poduzeća su ostvarivanje dobiti poslovanja i neograničenost vremena poslovanja. Računovodstvo evidentiranjem prati sve poslovne aktivnosti i procese i krajem obračunskog razdoblja sastavlja račun dobiti i gubitka, kao financijski izvještaj o 
rezultatima poslovanja. Dakle, račun dobiti i gubitka prikazuje obujam i strukturu prihoda i rashoda i dobit odnosno gubitak, kao financijski rezultat njihova sučeljavanja u određenom obračunskom razdoblju. Prema računovodstvenim standardima, strukturu računa dobiti i gubitka čine prihodi i rashodi poslovanja, pri čemu prihode čini prodajna vrijednost učinaka, a rashode vrijednosti uloga u poslovanju. U računu dobiti i gubitka prihodi su klasificirani kao poslovni i financijski prihodi poduzetnika, dok strukturu rashoda čine poslovni i financijski rashodi. Prikaz računa dobiti i gubitka kroz promatrane godine poslovanja odabranog poduzeća daje se u tablici u nastavku.

Tablica 2. Račun dobiti i gubitka 2014-2020.

\begin{tabular}{|c|c|c|c|c|c|c|c|}
\hline \multirow{2}{*}{ OPIS } & \multicolumn{7}{|c|}{ Godina } \\
\hline & 2014. & 2015. & 2016. & 2017. & 2018. & 2019. & 2020. \\
\hline 1. Poslovni prihodi & 1.326 .514 & 8.139 .360 & 10.186 .504 & 16.380 .766 & 24.341 .049 & 29.629.547 & 28.456 .162 \\
\hline 2. Poslovni rashodi & 1.324 .927 & 7.716 .606 & 9.851 .839 & 16.351 .240 & 24.324.537 & 28.505 .015 & 27.399.245 \\
\hline 2.1. Materijalni troškovi & 1.184 .106 & 6.637 .000 & 8.087 .291 & 13.326 .634 & 19.172 .544 & 20.483 .399 & 18.023 .922 \\
\hline 2.2. Troškovi osoblja & 126.673 & 674.963 & 1.425 .996 & 2.217.722 & 3.388 .039 & 3.675 .313 & 4.217 .569 \\
\hline 2.3. Amortizacija & 0 & 60.544 & 97.228 & 101.858 & 868.109 & 2.543 .560 & 3.238 .421 \\
\hline 2.4. Ostali troškovi & 14.148 & 196.193 & 220.896 & 367.411 & 419.121 & 1.802 .743 & 1.239 .607 \\
\hline 2.5. Rezerviranja & 0 & 0 & 0 & 337.615 & 476.724 & 0 & 679.726 \\
\hline 2.6. Ostali rashodi & 0 & 0 & 20.428 & 0 & 0 & 0 & 0 \\
\hline 3. Financijski prihodi & 0 & 29.667 & 6.323 & 412.102 & 616.929 & 12.105 & 43.613 \\
\hline 4. Financijski rashodi & 0 & 48.676 & 9.893 & 460.258 & 117.092 & 514.107 & 455.208 \\
\hline 6. Ukupni prihodi & 1.326 .514 & 8.169 .267 & 10.192 .827 & 17.292 .868 & 24.957 .978 & 29.641 .652 & 28.499.775 \\
\hline 7. Ukupni rashodi & 1.324.927 & 7.765 .282 & 9.861 .732 & 16.811 .498 & 24.441 .629 & 29.019.786 & 27.854 .453 \\
\hline 8. Dobit prije poreza & 1.587 & 403.985 & 331.095 & 481.370 & 516.349 & 621.866 & 645.322 \\
\hline 9.Porez na dobit & 317 & 84.508 & 72.356 & 106.686 & 104.376 & 150.740 & 62.799 \\
\hline 10. Dobit razdoblja & 1.270 & 319.477 & 258.739 & 374.684 & 411.973 & 471.126 & 582.523 \\
\hline
\end{tabular}

Izvor: Rad autora

\subsection{Ostali financijski izvještaji}

Osim navedenih, mali poduzetnik je dužan sastavljati i Bilješke uz financijske izvještaje koje svojim sadržajem dodatno pojašnjavaju sadržaj prednjih dvaju financijskih izvještaja. Iste navodimo radi prikaza sveobuhvatnosti sadržaja temeljnih financijskih izvještaja, međutim predmetom naše analize su samo bilanca i račun dobiti, kao najvažniji izvori informacija za potrebe poslovnog odlučivanja. 


\section{ANALIZA FINANCIJSKIH IZVJEŠTAJA}

Sadržajno, analiza podrazumijeva ispitivanje financijskog stanja poduzeća i uspješnosti poslovanja u funkciji donošenja poslovnih odluka pa se kao takva primarno povezuje s upravljanjem i planiranjem poslovanja. Analizom se razmatraju posljedice različitih upravljačkih odluka, a rezultati analize su potom informacijska podloga za planiranje, poslovno odlučivanje i upravljanje poduzećem. „Zato se financijsko stanje u kontekstu donošenja tih odluka može promatrati kao kumulativni rezultat investicijskih i financijskih odluka, a uspješnost poslovanja s pomoću neto učinka poslovanja (dobiti ili gubitka) u određenom razdoblju prema utjecaju na vlasničku glavnicu“ (Tintor, 2014, str. 42). Stoga se i analiza financijskih izvještaja primarno raspravlja s aspekta upravljačkih odluka, kako onih u vezi s tekućim poslovanjem tako i upravljačkih odluka u vezi s razvojem, što podrazumijeva i upravljačke odluke u procesu planiranja.

Brojne su metode analize financijskih izvještaja, a u procesu analiziranja moguće se služiti različitim postupcima koji su utemeljeni na raščlanjivanju i uspoređivanju podataka. Međutim, osnovna klasifikacija analitičkih postupaka financijskih izvještaja obuhvaća horizontalnu (komparativnu) i vertikalnu (strukturnu) analizu financijskih izvještaja, potom pojedinačne i skupne financijske pokazatelje te zbrojne, odnosno sintetičke pokazatelje. U našem ćemo slučaju koristiti i specijalnu metodu indeksnih brojeva, koja na praktičan način prikazuje trend kretanja pozicija financijskih izvještaja u promatranom razdoblju. Za potrebe ove analize koristimo bilancu i račun dobiti i gubitka odabranog poduzeća.

\subsection{Analiza trenda}

Analiza trenda temelji se na metodi indeksnih brojeva koja se često koristi jer na jednostavan način prikazuje trend kretanja pozicija financijskih izvještaja. Namjera nam je da kroz prikaz trenda kretanja pozicija bilance, dakle financijskog stanja poduzeća, odnosno trend kretanja rezultata poslovnog uspjeha prema računu dobiti i gubitka, prikažemo razvojni put poduzeća s komentarima ključnih upravljačkih odluka na tom putu.

Indeksna metoda podrazumijeva pretvorbu apsolutnih brojeva u relativne na način da se bilančne stavke početne godine poslovanja izjednačavaju sa 100, a iste stavke preračunavaju na toj osnovi u narednim godinama poslovanja. Tako se za svaku godinu poslovanja može vidjeti u kojoj su mjeri pojedine stavke financijskog stanja porasle, a koje su se smanjile u odnosu referentne veličine. Radi preglednosti kretanja prikazom ćemo obuhvatiti samo temeljne kategorije bilance i računa dobiti i gubitka. 
Tablica 3. Indeksni brojevi bilance

\begin{tabular}{|l|r|r|r|r|r|r|r|}
\hline \multirow{2}{*}{ OPIS } & \multicolumn{7}{|c|}{ Godina } \\
\cline { 2 - 9 } & 2014. & 2015. & 2016. & 2017. & 2018. & 2019. & 2020. \\
\hline 1. Dugotrajna imovina & 100 & 77 & 384 & 4476 & 13.893 & 20.479 & 20.466 \\
\hline 2. Kratkotrajna imovina & 100 & 201 & 331 & 570 & 595 & 679 & 985 \\
\hline UKUPNO AKTIVA & 100 & 193 & 334 & 831 & 1484 & 2.002 & 2285 \\
\hline 3. Kapital i rezerve & 100 & 1602 & 2524 & 4378 & 6314 & 28.380 & 28.520 \\
\hline 4. Rezerviranja & 100 & - & - & - & - & - & - \\
\hline 5. Dugoročne obveze & 100 & - & - & - & - & - & - \\
\hline 6. Kratkoročne obveze & 100 & 148 & 272 & 417 & 375 & 361 & 428 \\
\hline UKUPNO PASIVA & 100 & 193 & 334 & 831 & 1484 & 2002 & 2285 \\
\hline
\end{tabular}

Izvor: Rad autora

Iz prikazanih indeksnih brojeva možemo razabrati da je tijekom sedmogodišnjeg poslovanja financijsko stanje poduzeća višestruko povećano jer je ukupni indeks povećanja bilance 2285. U strukturi aktive izuzetno visoko povećanje je kod dugotrajne imovine gdje je indeks 20.446, što se tumači činjenicom da je početna vrijednost dugotrajne imovine bila minimalna u prvoj godini poslovanja, a da su ozbiljnija ulaganja započela u trećoj s nastavkom u četvrtoj godini poslovanja. Ista se situacija ponavlja i u sedmoj godini započetim ulaganjima od oko 5 milijuna kuna, s tim da će se indeks rasta znatno povećati u osmoj godini stavljanjem u funkciju novonabavljene opreme. Kratkotrajna imovina također pokazuje visok indeks povećanja, ali se realno radi o znatno manjoj vrijednosti i rastu u usporedbi s dugotrajnom imovinom. U strukturi bilančne pasive, najveći rast imaju dugotrajne obveze, s tim da isti nije moguće iskazati indeksnim brojevima jer u početnoj godini dugoročnih obveza nije niti bilo, kao što je slučaj i s rezerviranjima, s tim da potonja nemaju značajniju visinu niti bilančni kontinuitet.

Dakle, možemo zaključiti da ako izuzmemo početnu godinu poslovanja, za koju je već rečeno da temeljne upravljačke odluke čine osnivanje poduzeća i početak poslovanja zasnovanog na vlastitim financijskim sredstvima, dobrom poznavanju proizvodnog procesa, posebno u segmentu laserske obrade i dorade metala, i poznavanju tržišta tih proizvoda i usluga, može se prepoznati kontinuirani rast financijskog stanja, s posebnim naglaskom na treću i sedmu godinu poslovanja. Koje su to upravljačke odluke kojima se u tim godinama bitno mijenja ukupno financijsko stanje, kao i njegova bilančna struktura?

U trećoj godini poslovanja stečeni su bonitetni uvjeti koji omogućuju donošenje i realizaciju upravljačkih odluka o preuzimanju bankarskih kredita za potrebe investicija i trajnih obrtnih sredstava s jedne strane i plasmana tih sredstava u opremanje proizvodnje kupnjom i najmom opreme s druge strane. Dio tih upravljačkih odluka djelomično je realiziran u trećoj, a dijelom u četvrtoj godini poslovanja, posebno kad je riječ o ulaganjima u vlastitu dugotrajnu imovinu poduzeća. To su ulaganja u strojeve, kupnju zemljišta i početak izgradnje vlastitog proizvodnog i poslovnog prostora. Odluka o izgradnji vlastitog proizvodnog i poslovnog prostora zasnovana je na proračunu odnosa visine dotadašnje najamnine i visine obveza po kreditima za izgradnju vlastitih proizvodnih i poslovnih prostora. Osim toga, unajmljeni prostor svojom veličinom onemogućavao je realizaciju razvojnih planova 
ulaganja u suvremenu opremu potrebnu za rast proizvodnje i zadovoljavanje zahtjeva tržišta.

Preseljenjem u vlastiti prostor nastavlja se proces rasta proizvodnje i prometa proizvoda, što je zahtijevalo nova ulaganja u opremu koja će omogućiti daljnje povećanje proizvodnje i prometa i izlazak na nova tržišta. Pod novim tržištima podrazumijeva se izlazak na tržišta zemalja u okruženju i zemalja EU-a. Izlazak na zapadno europsko tržište postavlja nove izazove u pogledu tražene vrste i kvalitete proizvoda i usluga. To uvjetuje potrebu nabavke opreme koja će to omogućiti. Stoga se u sedmoj godini poslovanja ponovo donose upravljačke odluke o nabavci najsuvremenije opreme za lasersko rezanje i obradu svih vrsta metala. Iz prikazane bilance i indeksnih brojeva može se razabrati da je riječ o novim dugoročnim kreditima te da je dio tih kreditnih linija pretvoren u dugotrajnu imovinu, a glavni dio realizacije nabavke opreme zbiva se u trenutku pisanja ovog rada. To će omogućiti značajan porast proizvodnje, najviši stupanj kvalitete obrade metala i u konačnici daljnje jačanje tržišne pozicije na zahtjevnom zapadnoeuropskom tržištu te rast prihoda i dobiti poduzeća.

Tablica 4. Indeksni brojevi računa dobiti i gubitka

\begin{tabular}{|l|r|r|r|r|r|r|r|}
\hline \multirow{2}{*}{ OPIS } & \multicolumn{7}{|c|}{ Godina } \\
\cline { 2 - 8 } & 2014. & 2015. & 2016. & 2017. & 2018. & 2019. & 2020. \\
\hline 1. Poslovni prihodi & 100 & 613 & 768 & 1234 & 1834 & 2233 & 2144 \\
\hline 2. Poslovni rashodi & 100 & 582 & 763 & 1234 & 1836 & 2151 & 2068 \\
\hline 3. Financijski prihodi & 100 & - & - & - & - & - & - \\
\hline 4. Financijski rashodi & 100 & - & - & - & - & - & - \\
\hline 5. Ukupni prihodi & 100 & $\mathbf{6 1 6}$ & $\mathbf{7 6 8}$ & $\mathbf{1 3 0 3}$ & $\mathbf{1 8 8 1}$ & $\mathbf{2 2 3 3}$ & $\mathbf{2 1 4 8}$ \\
\hline 6. Ukupni rashodi & $\mathbf{1 0 0}$ & $\mathbf{5 8 6}$ & $\mathbf{7 4 4}$ & $\mathbf{1 2 6 9}$ & $\mathbf{1 8 4 6}$ & $\mathbf{2 1 9 2}$ & $\mathbf{2 1 0 4}$ \\
\hline 7. Dobit prije poreza & $\mathbf{1 0 0}$ & $\mathbf{2 5 4}$ & $\mathbf{2 0 7}$ & $\mathbf{3 0 3}$ & $\mathbf{3 2 5}$ & $\mathbf{3 9 2}$ & $\mathbf{4 1 9}$ \\
\hline
\end{tabular}

Izvor: Rad autora

Prema tablici indeksnih brojeva pozicija računa dobiti i gubitka, razabire se kontinuirani rast prihoda, koji na nešto nižoj razini prati rast rashoda, pri čemu je važna činjenica da poslovni prihodi čine gotovo u cijelosti ukupne prihode poduzeća jer je financijski prihod zanemariv. Kod rashoda je nešto drugačija situacija. Također dominiraju poslovni rashodi u strukturi ukupnih rashoda, ali s ulaganjima u dugotrajnu imovinu raste udio financijskih rashoda po osnovi kamata na kredite. Indeks rasta ukupnih prihoda iznosi $2144 \mathrm{u}$ sedmogodišnjem razdoblju poslovanja i relativno je ravnomjeran raspored njegova rasta. Isti je slučaj i s ukupnim rashodima, s tim da oni imaju značajno učešće u prihodima, pa ostvarena dobit ima relativno malo učešće u ukupnim prihodima. U početku je to rezultat niske produktivnosti, a u kasnijim godinama poslovanja rezultat rasta financijskih rashoda. Pored već spomenutih upravljačkih odluka u analizi indeksnih brojeva bilance, značajne upravljačke odluke u vezi s tekućim poslovanjem koje treba izdvojiti su odluke povezane s prilagodbom organizacije poslovanja brzom rastu opsega proizvodnje i tržišta, potom odluke u vezi s financiranjem tekućeg poslovanja i odluke u vezi s pribavljanjem i stalnim stručnim usavršavanjem zaposlenika te razvojem odnosa s kupcima i dobavljačima. 


\subsection{Horizontalna i vertikalna analiza financijskih izvještaja}

Horizontalna i vertikalna analiza financijskih izvještaja, točnije bilance i računa dobiti i gubitka, temeljni su instrument i postupak analize financijskih izvještaja. Pomoću horizontalne ili komparativne analize uočavamo tendencije i dinamiku promjena pojedinih pozicija financijskih izvještaja. Inačica horizontalne analize je analiza trenda, pri kojem se pomoću postotaka kroz duže vremensko razdoblje promatra dinamika promjena pozicija financijskih izvještaja. Vertikalna ili strukturna analiza nam omogućava uvid u strukturu i promjene u strukturi financijskih izvještaja. Budući da smo u prethodnom poglavlju dali osvrt na analizu trenda koristeći metodu indeksnih brojeva, u ovom dijelu rada dajemo prikaz horizontalne i vertikalne analize bilance i računa dobiti i gubitka poduzeća.

Horizontalna analiza financijskih izvještaja podrazumijeva usporedbu podataka iz financijskih izvještaja za dvije ili više godina prikazanu u odgovarajućoj analitičkoj tablici. Takav prikaz financijskih izvještaja naziva se i komparativnim financijskim izvještajem. „Komparativni financijski izvještaji koji služe kao podloga za provedbu horizontalne analize mogu se razmatrati u kontekstu uspoređivanja. Horizontalnom analizom nastoje se uočiti tendencije i dinamika promjena pojedinih pozicija temeljnih financijskih izvještaja. Na temelju tih promjena prosuđuje se kakva je uspješnost i sigurnost poslovanja promatranog poduzeća,, ( Gulin, Tušek i Žager, 2004, str. 179). Smatra se primarnim oblikom ispitivanja financijskih izvještaja jer se ispitivanje svodi na utvrđivanje apsolutne i postotne razlike među istovrsnim podacima za razdoblje od dvije ili više godina. Komparativna analiza nam pomaže u razumijevanju toga poboljšava li se ili pogoršava poslovanje poduzeća u odnosu na kretanja u prošlosti, ali nam pomaže i u procjenjivanju budućih trendova. Tu je potrebno biti oprezan jer se okruženje i uvjeti u kojima se posluje neprekidno mijenjaju.

Vertikalna analiza financijskih izvještaja omogućava uspoređivanje pojedinih elemenata strukture financijskih izvještaja radi otkrivanja promjena i važnosti međusobnih odnosa pojedinih pozicija financijskih izvještaja. Osnova vertikalne analize jesu strukturni financijski izvještaji pa je poznajemo i kao strukturnu analizu financijskih izvještaja. „Strukturni financijski izvještaji koji služe kao podloga za provedbu vertikalne analize mogu se razmatrati u kontekstu raščlanjivanja. Vertikalna analiza omogućava uvid u strukturu financijskih izvještaja“ (Gulin, Tušek i Žager, 2004, str. 179). Strukturiranje se postiže tako da se odredi bazna pozicija financijskog izvještaja koja se izjednačava sa 100, a potom se sve druge pozicije strukture izračunavaju kao postotak od bazne pozicije. Strukturiranje bilance provedeno je na način da se ukupna aktiva i pasiva izjednačavaju sa 100 , a potom se sve pozicije aktive, odnosno pasive izračunavaju kao postotak od ukupne aktive ili pasive, dok se kod računa dobiti i ukupni prihod izjednačava sa 100 , a potom se sve pozicije računa dobiti i gubitka izračunavaju kao postotak od ukupnog prihoda.

$\mathrm{U}$ vezi s provedenom financijskom analizom i prikazom dobivenih informacija imamo nekoliko napomena. Prvo, za potrebe financijske analize korišteni su podaci iz bilance i računa dobiti i gubitka, s tim da su u prezentiranim tablicama reducirani na skupne pozicije financijskih izvještaja kako bi se postigle bolja preglednost i usporedivost podataka. Drugo, uobičajeno je da se pri provođenju analize financijskih izvještaja komparativni prikazi bilance, odnosno računa dobiti i gubitka prikazuju odvojeno od strukturnog prikaza bilance i računa dobiti i gubitka, ali radi jednostavnijeg prikaza, bolje preglednosti podataka i informacija te njihove međuovisnosti, $u$ istoj tablici prikazani su postupak i rezultat horizontalne i vertikalne analize financijskih izvještaja, zasebno o financijskom stanju 
odnosno bilančni podaci, od podataka o rezultatima poslovanja prema računu dobiti i gubitka. Treće, u prethodnom smo poglavlju metodom indeksnih brojeva prikazali trend kretanja financijskog stanja i rezultata poslovanja kroz sve godine poslovanja poduzeća, s prikazom ključnih upravljačkih odluka u vezi s tim kretanjima i rezultatima. Stoga su u ovom dijelu rada provedene horizontalna i vertikalna analiza financijskih izvještaja samo za zadnje dvije godine poslovanja, koje su karakteristične u odnosu na ostale godine poslovanja po tome što se u 2020. godini poslovalo u specifičnom okruženju uvjetovanom globalnom pandemijom. Takav pristup je odabran kako bi se dodatno sagledale upravljačke odluke i njihovi rezultati na poslovanje i razvoj poduzeća u uvjetima globalne pandemije.

Tablica 5. Komparativna i strukturna bilanca

\begin{tabular}{|c|c|c|c|c|c|}
\hline OPIS & 2019. & $\%$ & 2020. & $\%$ & Index \\
\hline 2 & 3 & 6 & 5 & 6 & $8(5 / 3)$ \\
\hline A. Dugotrajna imovina & 14.086 .588 & 68 & 14.064 .418 & 60 & 100 \\
\hline 1. Nematerijalna imovina & 1.065 .056 & 5 & 1.863 .223 & 8 & 175 \\
\hline 2. Materijalna imovina & 12.985 .472 & 63 & 12.201.193 & 52 & 94 \\
\hline 3. Financijska imovina & 0 & 0 & 0 & 0 & - \\
\hline 4. Potraživanja & 36.061 & 0 & 0 & 0 & 106 \\
\hline B. Kratkotrajna imovina & 6.563 .334 & 32 & 9.461 .574 & 40 & 144 \\
\hline 1. Novac & 384.537 & 2 & 946.027 & 4 & 246 \\
\hline 2.Financijska imovina & 246.705 & 1 & 481.828 & 2 & 201 \\
\hline 3. Potraživanja & 4.143 .337 & 20 & 5.610 .896 & 24 & 136 \\
\hline 4. Zalihe & 1.788 .755 & 9 & 2.422 .824 & 10 & 135 \\
\hline C. UKUPNO AKTIVA & 20.649 .923 & 100 & 23.525 .992 & 100 & 114 \\
\hline A. Kapital i rezerve & 6.068 .461 & 29 & 6.068 .035 & 26 & 100 \\
\hline 1. Upisani kapital & 1.170 .700 & 6 & 1.170 .700 & 5 & 100 \\
\hline 2. Rezerve & 2.264 .101 & 11 & 1.681 .152 & 7 & 74 \\
\hline 3. Zadržana dobit & 2.130 .546 & 10 & 2.633 .660 & 11 & 124 \\
\hline 4. Dobit poslovne godine & 503.114 & 2 & 582.524 & 2 & 116 \\
\hline B. Rezerviranja & 0 & 0 & 679.726 & 3 & - \\
\hline C. Dugoročne obveze & 10.933 .486 & 53 & 12.461 .591 & 53 & 113 \\
\hline D. Kratkoročne obveze & 3.647 .976 & 18 & 4.316 .640 & 18 & 118 \\
\hline E. UKUPNO PASIVA & 20.649 .923 & 100 & 23.525 .992 & 100 & 114 \\
\hline
\end{tabular}

Izvor: Rad autora

Prema prezentiranim podacima iz prethodne tablice, vidljive su značajne promjene $u$ financijskom stanju poduzeća. Unatoč poslovanju u uvjetima globalne pandemije, većina promjena može se ocijeniti pozitivnima. Bilančna aktiva i pasiva su povećane za oko 14 \%, s tim da je u strukturi došlo do povećanja udjela kratkotrajne imovine i slobodnog radnog kapitala. U aktivi nema značajnijih promjena jer je umanjenje imovine amortizacijom nadoknađeno novim ulaganjima u dugotrajnu imovinu, glavnina čega će biti realizirana u 
tekućoj godini, o čemu je već pisano u prethodnom poglavlju rada. Nema niti značajnijih promjena u strukturi pasive, ali je potrebno naglasiti da je rast potraživanja rezultat povećanih isporuka krajem godine, dok je rast zaliha u segmentu sirovina i materijala rezultat povećanih ulaganja zbog najave visokog rasta cijena sirovina, čime su stvorene značajne skrivene rezerve u vrijednosti sirovina i materijala.

Tablica 6. Komparativni i strukturni račun dobiti i gubitka

\begin{tabular}{|c|c|c|c|c|c|}
\hline OPIS & 2019. & $\%$ & 2020. & $\%$ & Index \\
\hline 1 & 2 & 3 & 4 & 5 & $6(4 / 2)$ \\
\hline I. POSLOVNI PRIHODI & 29.629.547 & 100 & 28.456.162 & 100 & 96 \\
\hline II. POSLOVNI RASHODI & 28.505 .015 & 96 & 27.399.245 & 96 & 96 \\
\hline 1. Promjena vrijednosti zaliha & 0 & 0 & 0 & 0 & 0 \\
\hline 2. Materijalni troškovi & 20.483.399 & 69 & 18.023 .922 & 74 & 96 \\
\hline - troškovi sirovina i materijala & 1.788 .620 & 6 & 312.055 & 1 & 17 \\
\hline - troškovi prodane robe & 14.405 .823 & 49 & 12.545 .198 & 44 & 87 \\
\hline - ostali vanjski troškovi & 4.288 .956 & 14 & 5.166 .669 & 18 & 120 \\
\hline 3. Troškovi osoblja & 3.675 .313 & 12 & 4.217.569 & 15 & 115 \\
\hline - neto plaće i nadnice & 2.450 .906 & 8 & 2.755 .526 & 10 & 112 \\
\hline - troškovi poreza i doprinosa iz plaća & 838.543 & 3 & 980.996 & 3 & 117 \\
\hline - doprinosi na plaće & 385.864 & 1 & 481.047 & 2 & 125 \\
\hline 4. Amortizacija & 2.543 .560 & 9 & 3.238 .421 & 11 & 127 \\
\hline 5. Ostali troškovi & 1.802 .743 & 6 & 1.239 .607 & 4 & 69 \\
\hline 6. Vrijednosno usklađivanje & 0 & 0 & 0 & 0 & 0 \\
\hline 7. Rezerviranja & 0 & 0 & 679.726 & 2 & . \\
\hline 8. Ostali poslovni rashodi & 0 & 0 & 0 & 0 & 0 \\
\hline II. FINANCIJSKI PRIHODI & 12.105 & 0 & 43.613 & 0 & 367 \\
\hline 1. Kamate & 1.417 & 0 & 2.299 & 0 & 157 \\
\hline 2. Tečajne razlike & 10.688 & 0 & 41.314 & 0 & 373 \\
\hline 3. Ostali financijski prihodi & 0 & 0 & 0 & 0 & 0 \\
\hline IV. FINANCIJSKI RASHODI & 514.770 & 2 & 455.208 & 2 & 88 \\
\hline 1. Kamata & 356.927 & 2 & 363.211 & 2 & 102 \\
\hline 2. Tečajne razlike & 136.613 & 0 & 91.997 & 0 & 67 \\
\hline 3. Ostali financijski rashodi & 21.230 & 0 & 0 & 0 & - \\
\hline IX. UKUPNI PRIHODI & 29.641 .652 & 100 & 28.499.775 & 100 & 96 \\
\hline X. UKUPNI RASHODI & 28.980 .776 & 98 & 27.854 .453 & 98 & 96 \\
\hline XI. DOBIT PRIJE OPOREZIVANJA & 660.876 & 2 & 645.322 & 2 & 98 \\
\hline XII. POREZ NA DOBIT & 157.762 & 0.4 & 62.799 & 0,2 & 40 \\
\hline XIII. DOBIT ILI GUBITAK RAZDOBLJA & 471.126 & 1,6 & 582.523 & 1,8 & 124 \\
\hline
\end{tabular}

Izvor: Rad autora 
Iz prethodne tablice vidljivo je smanjenje prihoda u pandemijskoj godini poslovanja za oko 4 \%. Smanjenje prihoda prati razmjerno smanjenje rashoda pa je u konačnici ostvaren pozitivan financijski rezultat na razini pretpandemijske godine, a zahvaljujući nižem porezu na dobit, u konačnici je ostvarena dobit razdoblja na razini za oko 24 \% većoj od one u pretpandemijskoj godini. Zbog toga se, unatoč smanjenim prihodima, poslovanje poduzeća u pandemijskoj godini smatra uspješnim. Tome su, među ostalim pridonijele upravljačke odluke otvaranja novih tržišta zbog smanjene ponude konkurencije, novi kanali prodaje u inozemstvu, pravovremena nabavka sirovina prije povećanja cijena i dr. Valja napomenuti da je u istom razdoblju većina poduzeća metaloprerađivačke djelatnosti ostvarila pad prihoda od $5 \%$ do $25 \%$, ovisno o proizvodnom asortimanu i prodajnim tržištima.

\subsection{Pojedinačni i skupni pokazatelji}

Najznačajniji pojedinačni i skupni pokazatelji financijske analize su pokazatelji likvidnosti, pokazatelji zaduženosti, pokazatelji aktivnosti, pokazatelji ekonomičnosti i pokazatelji profitabilnosti. U nastavku su prezentirani njihov prikaz i usporedno kretanje u pandemijskoj prema prethodnoj godini poslovanja.

Tablica 7. Pokazatelji likvidnosti

\begin{tabular}{|l|l|c|c|c|}
\hline \multicolumn{1}{|c|}{ Pokazatelji } & \multicolumn{1}{|c|}{ Pozicije } & 2019. & 2020. & Indeks \\
\hline Koeficijent tekuće likvidnosti & Novac / KO & 1,78 & 2,19 & 123 \\
\hline Koeficijent ubrzane likvidnosti & Novac + potraživanje / KO & 1,31 & 1,63 & 124 \\
\hline Koeficijent financijske stabilnosti & DI / K + DO & 0,83 & 0,76 & 93 \\
\hline
\end{tabular}

Izvor: Rad autora

Pokazatelji likvidnosti su među najznačajnijim primarnim indikatorima financijskog stanja poduzeća. Naime, duža nelikvidnost vodi insolventnosti i mogućoj propasti poduzeća. Zato je nužno redovito pratiti i analizirati likvidnost, odnosno uzroke nelikvidnosti poduzeća. Najčešći pokazatelji likvidnosti jesu koeficijent tekuće likvidnosti, koeficijent ubrzane likvidnosti i koeficijent financijske stabilnosti. Prema prikazanoj Tablici 7. razabiru se dobri pokazatelji u usporedbi s referentnim veličinama likvidnosti i solventnosti u obje godine poslovanja te njihova tendencija rasta. Važno je napomenuti da je to realizirano poslovanjem u uvjetima globalne pandemije.

\section{Tablica 8. Pokazatelji zaduženosti}

\begin{tabular}{|l|l|c|c|c|}
\hline \multicolumn{1}{|c|}{ Pokazatelji } & \multicolumn{1}{|c|}{ Pozicije } & 2019 & 2020 & Indeks \\
\hline Koeficijent zaduženosti & UO / UI & 0,71 & 0,71 & 100 \\
\hline Koeficijent vlastitog financiranja & K/ UI & 0,29 & 0,29 & 100 \\
\hline Koeficijent financiranja & UO / K & 2,40 & 2,75 & 115 \\
\hline Pokriće troškova kamata & Dobit prije poreza i kamate / kamate & 2,39 & 2,42 & 110 \\
\hline
\end{tabular}

Izvor: Rad autora 
Zaduženost podrazumijeva da se poslovanje vodi posuđenim novcem. Najčešći pokazatelji zaduženosti su koeficijent zaduženosti, koeficijent vlastitog financiranja, koeficijent financiranja i pokriće troškova kamata. Temeljno je pravilo da će poduzetnik imati koristi od zaduživanja ako je stopa profitabilnosti veća od kamatne stope. Zbog toga se iz prezentirane Tablice 8. razabire relativno visoka zaduženost. Pritisak kamata je nešto ublažen jer se dio dugoročnih kredita financira beskamatno sredstvima vlasnika, a dio iz zadržane i tekuće dobiti. Važna je i namjena kreditnih sredstava. U ovom slučaju je riječ o investiranju u najsuvremeniju opremu pa su očekivanja rasta produktivnosti izvjesna, a time i zaduženost opravdana.

Tablica 9. Pokazatelji aktivnosti

\begin{tabular}{|l|l|r|r|r|}
\hline \multicolumn{1}{|c|}{ Pokazatelji } & \multicolumn{1}{|c|}{ Pozicije } & \multicolumn{1}{c|}{2019} & \multicolumn{1}{c|}{2020} & \multicolumn{1}{c|}{ Indeks } \\
\hline Koeficijent obrta UI & UP / UI & 1,43 & 1,21 & 85 \\
\hline Koeficijent obrta KI & UP / KI & 4,52 & 3,00 & 67 \\
\hline Koeficijent obrta potraživanja & Prihod od prodaje / Potraživanja & 7,25 & 5,24 & 72 \\
\hline Vrijeme naplate potraživanja & Broj dana u godini / KOP & 50 & 70 & 140 \\
\hline Koeficijent obrta zaliha & Prihod od prodaje / Zalihe & 16,57 & 11,76 & 73 \\
\hline Vrijeme trajanja zaliha & Broj dana u godini / KOZ & 22 & 31 & 141 \\
\hline
\end{tabular}

Izvor: Rad autora

Analiza aktivnosti daje odgovore na pitanja o sposobnosti generiranja dovoljnih obrtnih sredstava (radnog kapitala) za tekuće poslovanje i redovito plaćanje tekućih obveza. Pokazatelji aktivnosti mjere se pomoću koeficijenata obrta. Najčešće su to koeficijent obrta ukupne imovine, koeficijent obrta kratkotrajne imovine, koeficijent obrta potraživanja i koeficijent naplate potraživanja u danima. Na pokazateljima prikazanim u Tablici 9. razabire se cijena poslovanja u pandemijskim uvjetima. Smanjenje prihoda rezultat je smanjene aktivnosti, što je vidljivo prema tendenciji smanjenja svih koeficijenata aktivnosti poduzeća i produženog vremena naplate potraživanja i prosječnog vremena trajanja zaliha.

Tablica 10. Pokazatelji ekonomičnosti

\begin{tabular}{|l|l|r|r|r|}
\hline \multicolumn{1}{|c|}{ Pokazatelji } & \multicolumn{1}{|c|}{ Pozicije } & \multicolumn{1}{|c|}{2019.} & \multicolumn{1}{c|}{2020.} & Indeks \\
\hline $\begin{array}{l}\text { Ekonomičnost ukupnog } \\
\text { poslovanja }\end{array}$ & Ukupni prihodi / Ukupni rashodi & 1,02 & 1,02 & 100 \\
\hline Ekonomičnost poslovanja & $\begin{array}{l}\text { Poslovni prihodi / Poslovni } \\
\text { rashodi }\end{array}$ & 1,03 & 1,04 & 1,01 \\
\hline Ekonomičnost financiranja & $\begin{array}{l}\text { Financijski prihodi / Financijski } \\
\text { rashodi }\end{array}$ & 0,03 & 0,10 & 333 \\
\hline
\end{tabular}

Izvor: Rad autora 
Analiza ekonomičnosti pokazuje koliko svaka jedinica rashoda generira veći prihod, dakle upućuje na odnos prihoda i rashoda. Najčešći pokazatelji ekonomičnosti su ekonomičnost ukupnog poslovanja, ekonomičnost poslovanja i ekonomičnost financiranja. Koeficijenti ekonomičnosti uvijek bi trebali biti veći od 1. Iz podataka prikazanih u Tablici 10. razabire se da rast i razvoj poduzeća zasad ne prati i značajniji rast ekonomičnosti.

\section{Tablica 11. Pokazatelji profitabilnosti}

\begin{tabular}{|l|l|r|r|r|}
\hline \multicolumn{1}{|c|}{ Pokazatelji } & \multicolumn{1}{|c|}{ Pozicije } & 2019. & \multicolumn{1}{c|}{2020.} & \multicolumn{1}{c|}{ Indeks } \\
\hline Marža profita & Neto dobit i kamate / UP & 2,23 & 2,26 & 101 \\
\hline EBIT & Dobit prije poreza i kamate / UP & 3,08 & 3,86 & 101 \\
\hline Rentabilnost imovine & Neto dobit i kamate / UI & 4,74 & 4,40 & 93 \\
\hline Rentabilnost kapitala & Neto dobit / Kapital & 8,29 & 9,59 & 116 \\
\hline
\end{tabular}

Izvor: Rad autora

Profitabilnost pokazuje efikasnost poslovanja poduzetnika. Najvažniji pokazatelji su marža profita, EBIT, rentabilnost imovine i rentabilnost kapitala. Poput ekonomičnosti, i ovi pokazatelji upućuju na uspješnost poslovanja. Iz Tablice 11. razabiru se relativno pozitivni rezultati s tendencijom rasta, posebice jer su ostvareni u pandemijskoj godini poslovanja.

\subsection{Sustavi pokazatelja i sintetički pokazatelji}

Prethodno prikazani pojedinačni i skupni pokazatelji odnose se na pojedine segmente poslovanja. Stoga je, bez obzira na njihov broj, ograničeno njihovo korištenje radi zaključivanja o cjelini. Zbog toga se za sagledavanje cjeline koriste različiti složeni pokazatelji. „Pod sustavom ili sistemom pokazatelja podrazumijeva se izbor odgovarajućih pokazatelja, odgovarajući način njihova povezivanja ili odgovarajuća zavisnost i sveukupna zavisnost pojedinih pokazatelja i njihovog povezivanja s ciljem“ ( Tintor, 1983, str. 124). Najčešće se služimo dvama složenim sustavima pokazatelja, Du Pontovim sustavom analitičkih pokazatelja i Altmanovim Z-score sintetičkim pokazateljem financijske sigurnosti.

Tablica 12. Sustavi i sintetski pokazatelji

\begin{tabular}{|l|l|r|r|r|}
\hline \multicolumn{1}{|c|}{ Pokazatelji } & \multicolumn{1}{|c|}{ Pozicije } & \multicolumn{1}{c|}{2019.} & 2020. & Indeks \\
\hline Du Pontov sustav pokazatelja & Neto dobit i kamate / UP & 4,02 & 3,63 & 90 \\
\hline Altmanov Z-score indeks & Dobit prije poreza i kamate / UP & 2,11 & 1,97 & 93 \\
\hline
\end{tabular}

Izvor: Rad autora

Du Pontov sustav pokazatelja se koristi za potrebe planiranja poslovanja i poslovnog odlučivanja poduzetnika jer pokazuje rentabilnost ukupnog poslovanja. Izračun se temelji na umnošku marže profita (neto dobit + kamate / poslovni prihodi) i koeficijenta obrta ukupne imovine (poslovni prihodi / ukupna imovina). U našem slučaju, u pretpandemijskoj 
godini poslovanja ovaj pokazatelj rentabilnosti ukupne imovine iznosio je 4,02, dok je u 2020. godini iznosio 3,63 s tendencijom smanjenja. Uspoređujemo li navedene pokazatelje s prosječnom kamatnom stopom kredita, zahvaljujući relativno povoljnom stanju na kreditnom tržištu, zaključak je da su trenutno približno jednaki.

Altmanovom Z-score indeks najznačajniji je sintetički pokazatelj kojim se mjeri financijsko stanje poduzeća i procjenjuje mogućnost njegova stečaja. Izračunava se po formuli: $Z$ = $1,2 \times X 1+1,4 \times X 2+3,3 \times X 3+0,6 \times X 4+1,0 \times X 5$, pa je potrebno izračunati vrijednosti elemenata X1-X5 prema zadanim formulama. Ako je navedeni ponderirani zbroj veći od 3, tada to upućuje na stabilno poduzeće, veličina između 1 i 3 ukazuje na mogućnost pojave problema i poremećaje stabilnosti poduzeća, dok zbroj manji od 1 upućuje na prisutnost značajnih poteškoća u poslovanju i mogućnost stečaja u roku do dvije godine. U našem slučaju pokazatelj je u pretpandemijskoj godini 2,11 i smanjuje se u pandemijskoj godini poslovanja na 1,97, što veličinom i tendencijom kretanja upućuje na sivu zonu poslovanja i potrebu poduzimanja određenih mjera. Pretpostavka je da će se navedena situacija riješiti već u tekućoj godini s dvije značajne upravljačke mjere: prva je pretvaranje potraživanja vlasnika u upisani kapital, a druga povećanje i zadržavanje dobiti tekuće godine.

\section{PODUZETNIČKO OKRUŽENJE I POLITIKA PODUZETNIKA}

Poduzetničko okruženje čini splet institucionalnih rješenja u kojima djeluje poduzetnik i kojima se stalno mora prilagođavati, a sastoji se od ekonomskog, tehnološkog, društvenog, pravno-političkog i etičkog okruženja. Za razliku od poduzetničkog okruženja u razvijenim zemljama tržišne ekonomije u EU-u, s trajnim pravno-ekonomskim okvirima poslovanja, boljom tehničkom opremljenosti, etabliranim etičkim normama i brojnim nevidljivim mjerama kojima se u tim zemljama potiču poduzetništvo, konkurencija i gospodarski razvoj, situacija u našoj zemlji je nešto drugačija. Krene li se od pravno-političkog i ekonomskog okruženja, koji su povezani i međuovisni, unatoč brojnim mjerama što ih poduzima država, još uvijek su birokratske zapreke velike, brojne poduzetničke inicijative se sporo ili uopće ne rješavaju, pa istovremeno imamo neiskorištene resurse i velike naknade za njihovo aktiviranje. Bankarski sustav je rigidan za male poduzetnike, a kod kupaca i dobavljača razvoj trajnih poslovnih odnosa usporava izostanak trajnih, sigurnih i poticajnih pravno-ekonomskih okvira poslovanja. Tehnološko okruženje podrazumijeva inovativnost, uvođenje novih tehnologija i usvajanje stručnih znanja, što je nedostižno bez ozbiljnih državnih subvencija i poticaja. Štoviše, ne tako davno ukinute su korisne poticajne mjere neoporezivanja reinvestirane dobiti i priznavanja troškova samofinanciranja, a uvedeno dodatno oporezivanje dobiti uvođenjem poreza na dohodak. Društvenim okruženjem, koje čine brojni sustavi vrijednosti, sve više dominira problem ljudskog kapitala koji postaje važniji od tehnologije jer ona se može kupiti, a za stvaranje ljudskog kapitala potrebno je vrijeme stjecanja znanja i iskustva. Zato smo i na ovom području mišljenja da se nedovoljno potiče i usmjerava prema stvarnim potrebama današnje, a još više buduće tehnologije koja otvara vrata prema svjetskom tržištu. Etičko okruženje podrazumijeva moralnost poslovnih odluka, poštovanje konkurencije, potrošača i zaposlenika, što je danas u nesigurnim uvjetima poslovanja sve češće dvojbeno, a ponekad i protuzakonito bez adekvatne zaštite suprotne strane. 
U prednjim okvirima razvijala se poslovna politika poduzetnika odabranog poduzeća. Na određeni način čine je čarobne riječi: menadžment, organizacija, planiranje i etičke načela. Mada je riječ o uobičajenim terminima, sagledajmo njihovu primjenu u ovom poduzeću i ulogu menadžmenta u donošenju ključnih upravljačkih odluka.

„Menadžment je proces rada s drugima i pomoću drugih na ostvarivanju organizacijskih ciljeva u promjenjivu okruženju uz efektivnu i efikasnu uporabu ograničenih resursa" ( Drucker, 1992, str. 3). Polazna premisa vlasnika kao glavnog menadžera u ovom poduzeću jest da upravljanje predstavlja proces svjesnog usmjeravanja poduzeća nekim ciljevima te da podrazumijeva donošenja poslovnih odluka i odgovornost za njihove posljedice. Zbog toga se u donošenju upravljačkih odluka vlasnik vodi principom da za svaku odluku konzultira stručni tim poduzeća, da analizira njezinu potrebu, da procjenjuje posljedice i da za one koje odluke po svojem značenju i složenosti nadilaze kapacitete zaposlenika uvijek prije donošenja traži participaciju vanjskih stručnjaka o tim pitanjima.

Nezaobilazna je činjenica da je u biznisu sve nesigurno osim troškova pa je potrebno učiniti puno toga da se cjelokupni poslovni proces stavi pod kontrolu i usmjerava ka željenim ciljevima. Odgovor na to jest u organizaciji. Stoga je vlasnik postavio jednostavni funkcionalni tip organizacije, od marketinga s komercijalom, proizvodnje s projektnim centrom, financijske funkcije i općih poslova do funkcije kontrolinga, s jasno definiranim kompetencijama i odgovornostima na svim razinama, koja osigurava brzi prijenos informacije i pravovremeno kvalitetno odlučivanje.

O planiranju stav je vlasnika da ako ne analiziraš gdje si i ne odrediš kuda ideš, nikad nećeš stići na odredište. Zato se planiranju kao predviđanju budućnosti, procjeni rizika i ocjeni vlastitih sposobnosti za njihovo savladavanje daje veliko značenje u poduzeću. Osim godišnjeg plana razrađuje se kvartalni i analizira izvršenje plana tijekom godine. Planiraju se svi segmenti poslovanja, nadzire provedba i prema potrebi prilagođava promjenama u okruženju. Tako je, naprimjer, svakoj investicijskoj odluci prethodio poduzetnički projekt kojim su elaborirane sve sastavnice plana ulaganja s ocjenom njegove učinkovitosti i povratom investicije. Samo se na taj način moglo održati kontinuitet poslovanja i rast kroz promatrano razdoblje.

Etička načela mogu se raspravljati s različitih aspekata. Kada je riječ o etičkim načelima u poduzetništvu, podrazumijevaju se pisana i nepisana pravila kojima se uređuju organizacija i poslovna kultura komuniciranja unutar organizacije i s vanjskim sudionicima poslovanja. Tim su načelima obuhvaćena pravila moralnog poslovanja spram zaposlenika, poput pravičnog nagrađivanja, sukoba interesa i čuvanja poslovne tajne, razvoja međuljudskih odnosa i sl,, kao i moralno ponašanje spram vanjskih sudionika, poput poštivanja propisa i ugovora, standarda u poslovnom ponašanju, izbjegavanja lažnih obećanja i predstavljanja i sl. Pisanim etičkim kodeksom transparentno su regulirana sva etička pitanja na relaciji vlasnik i menadžeri - zaposlenici, kao i njihovi međusobni odnosi te sva pitanja etičkog ponašanja i normi spram kupaca i dobavljača i drugih vanjskih sudionika poslovanja. Etičkim pravilima i načelima komuniciranja unutar poduzeća nastoje se postići ugodnost rada, sigurnost zaposlenja, dobri međuljudski odnosi, poticajni motivi rada i učenja, privrženost poduzeću te poštivanje i etičan odnos prema vanjskim sudionicima. U odnosu na vanjske sudionike, uz već neke od nabrojenih etičkih standarda, poseban je naglasak na transparentnosti poslovnog odnosa, pridržavanju ugovorenog, kvaliteti učinaka, poštivanju rokova i financijskoj disciplini. 
Valja naglasiti da vlasnik i glavni menadžer poduzeća u svojem poslovanju, pored opće prihvaćenih poduzetničkih načela, primjenjuje i vlastitu upravljačku filozofiju koju temelji na biblijskim učenjima za poduzetničku praksu. Biblija sadrži brojne poslovne tajne koje se, kao bezvremenske istine, mogu primijeniti na posao i šire. Neke od njih sažeo je i interpretirao rabin Danijel Lapin u knjizi „Poslovne tajne iz Biblije“, od kojih ćemo neke prenijeti jer čine vlasnikovu duhovnu strategiju poslovanja poduzeća.

O poslovanju: „Istina je jednostavno da je poslovanje bilo koja osoba ili grupa ljudi koji imaju mušterije. Ako imate nekog spremnog dragovoljno vam platiti za posao koji radite, proizvod koji proizvodite ili uslugu koju pružate, tada ste u poslu... A kao ljudi - ako vam se sviđaju, cijenite ih i želite im služiti - bit ćete nagrađeni“ (Lapin, 2020, str. 20).

O stvaralaštvu: „Beskrajni Bog stvorio nas je po svom liku s beskrajnom maštom, potencijalom, stvaralačkom snagom i željama... Uzbudljiva je mogućnost beskonačnog ono je što pokreće poslovne profesionalce da uvijek traže bolje načine da što efikasnije služe što većem broju mušterija. To je ono što pokreće napredak u svijetu i sigurno je Božja volja“ (Lapin, 2020, str. 23, 25).

O povezivanju: „Svemir je stvoren za povezivanje... Teško je osporiti da onaj koji pomaže većem broju ljudi radi veće dobro od onoga koji pomaže nekolicini... Mjera za činjenje dobra za druge ljude bi, naravno, trebala biti koliko dobra činite za druge ljudi, a ne neka druga briga. Cilj je pokušati učiniti što je moguće više za što veći broj drugih ljudi“ (Lapin, 2020, str. 37).

O novcu, zarađivanju i dobiti: „Novac je duhovan... Zarađivanje novca jest duhovna aktivnost... Zarada i dobit Božji su način da nas nagradi za stvaranje veza i služenje drugima vjerno i učinkovito... Davanje novca automatski nas povezuje s drugim ljudima" ( Lapin, 2020, str. 47, 151, 265, 293).

O tržištu: „Bog želi da budemo posvećeni zadovoljavanju potreba i želja jedni drugima, a ako će dobri i milostivi Bog nagraditi one koji slijede njegove želje nevjerojatnim blagoslovom bogatstva, zašto bi nas i to iznenadilo... Otkrivati što drugi žele ili trebaju i osiguravati te stvari u što je moguće većem broju jedini je način da se zaradi novac neovisno o vašem zanimanju. Kako biste ovo efikasno učinili, trebate uspostaviti smislene odnose sa svojim mušterijama" (Lapin, 2020, str. 65).

O suradnji: „Možemo raditi sami ili surađivati s drugim ljudima, ali moramo zaraditi za život. Vrlo brzo otkrivamo da je raditi sam grozan način. Uključivanje u posao s drugim ljudima oduševljavajuće je, uzbudljivo i učinkovito. Bog želi da surađujemo, tako da je suradnju načinio učinkovitijom. On suradnju stavlja u centar procesa stvaranja novca dajući nam principe biznisa" (Lapin, 2020, str. 127).

O riziku: „Svi griješimo s vremena na vrijeme, ali rijetko griješimo namjerno. Ne nastojimo napraviti pogreške, one se jednostavno dogode. Svi smo pogrešivi. Ono što treba prihvatiti jest da ćete u životu i u poslu napraviti pogrešne korake, Pogriješit ćete s vremena na vrijeme i to će uzrokovati događanje loših stvari. Ali ne možemo se plašiti tih pogrešaka i ne možemo se plašiti njihovih posljedica. Budemo li se toga plašili, zatvorit ćemo se u strah od budućnosti. Nećemo uspjeti djelovati, nećemo uspjeti utrti sebi stazu kroz život i iz svojih pogrešaka" (Lapin, 2020, str. 227).

O vođenju: „Bit je služenja da ne možete voditi ako ne možete slijediti... Ljudi se neće dobrovoljno odreći svog novca i dati ga vama osim ako ste učinili nešto za njih. Prema 
tome, zarađivanje novca uvijek je čin služenja. Ovo vrijedi za zaposlene i za vlasnike biznisa jer svatko u biznisu ima mušterije koje treba služiti... Istinsko vodstvo znači dopustiti ljudima oko vas da vide vašu sposobnost da budete ponizni“ (Lapin, 2020, str. 169).

O promjenama i planiranju: „Promjena je neizbježna. Ona je stalna. Uključivat će i stres, a stres podrazumijeva i patnju... lako zastrašujuća i stresna, može nositi u sebi i sjeme rasta i dobre sreće. Ovo je jednako istinito u biznisu kao i na bojnom polju. Moramo ostati vjerni svojoj svrsi, ali prihvatiti da će se promjene događati, i prilagoditi svoje planove, ponašanje i poslovne taktike tako da ne izgubimo iz vida svoju osnovnu svrhu“ (Lapin, 2020, str. 191, 194).

\section{ZAKLJUČAK}

Ovaj rad je posvećen anatomiji poslovnog uspjeha i razvoja odabranog malog poduzeća iz metaloprerađivačke djelatnosti, od njegova osnutka 2014. godine do sadašnjeg vremena, odnosno zaključno s 2020. godinom. Navedeno sedmogodišnje razdoblje poslovanja, uz uobičajene tržišne izazove, odvijalo se u složenim tržišnim uvjetima poslovanja ekonomske recesije u ranijim godinama poslovanja te u složenim uvjetima poslovanja u vrijeme globalne pandemije uzrokovane bolešću COVID-19. Općenito promatrano, sve to je negativno utjecalo na gospodarski život u svijetu i u našoj zemlji, a time i na rizik poslovanje odabranog poduzeća.

Misija odabranog poduzeća jest da koristeći inovativne tehnologije i motivirane zaposlenike pruža vrhunske usluge i inovativna rješenja u djelatnosti primjenjujući visoke poslovne, ekološke i etičke standarde, na korist partnerima i dionicima. Vizija poduzeća jest postati vodeći regionalni inovativni servisni centar za usluge rezanja i strojnu obradu metala. Na tom se putu menadžment susreće s brojnim izazovima i rizicima u vođenju poslovnog sistema i donošenju upravljačkih odluka kojima nastoji osigurati optimalno tekuće poslovanje i ostvarivanje dobiti te vremensku neograničenost poslovanja izraženu kroz budući rast i razvoj poduzeća.

Cilj istraživanja bio je prepoznati navedene rizike i identificirati ključne upravljačke odluke i model upravljanja navedenim rizicima u danim tržišnim uvjetima. Provedena istraživanja upućuju na to da se, uz uobičajene rizike poslovanja i upravljačke odluke za njihovo rješavanje, tijekom promatranog vremena može razabrati nekoliko razdoblja u kojima je bilo nužno donošenje nekih ključnih upravljačkih odluka.

U početnom trogodišnjem razdoblju poslovanje obuhvaća samo pružanje usluga laserske obrade materijala korištenjem vlastitih izvora financiranja, polovne opreme i unajmljenog prostora pa se ključne upravljačke odluke odnose na istraživanje tržišta i uspostavu kanala prodaje te organizaciju proizvodnje. Istraživanjem tržišta uočena je mogućnost rasta prodaje usluga, ali i širenja ponuda usluga na vodeni rez, savijanje materijala i druge inovativne vrste proizvodnih usluga. Da bi se odgovorilo izazovima tržišta, donose se ključne upravljačke odluke nabave potrebne opreme za tu vrstu proizvodnje te zbog ograničenosti proizvodnih kapaciteta i upravljačke odluke glede organizacije rada u međusmjenskom i višesmjenskom režimu poslovanja. Značajna upravljačka odluka odnosi se i na trajnije opredjeljenje financiranja rasta i razvoja refinanciranjem zadržane dobiti. Rezultati su vidljivi u peterostrukom rastu prihoda i dobiti razdoblja. 
U narednom trogodišnjem razdoblja, uz rast domaćeg tržišta, otvaraju se i kanali prodaje u zemljama okruženja, a posebice u zemljama EU-a. Zahtjevno tržište EU-a očekuje striktno poštivanje rokova, dodatnu kvalitetu usluga i konkurentne cijene. To nameće potrebu donošenja više ključnih međusobno uvjetovanih upravljačkih odluka. Primarno se to odnosi na nabavku nove opreme većih kapaciteta i boljih radnih mogućnosti, uspostavljanje vlastitog projektnog biroa za vlastite potrebe i uslužno projektiranje, zapošljavanje i edukaciju kvalificirane radne snage te izgradnju i preseljenje u vlastiti proizvodni i poslovni prostor, a rast boniteta i kreditnog rejtinga omogućuje donošenje i realizaciju ključnih poslovnih odluka financiranja navedenih aktivnosti kreditima financijskih institucija. Rezultati su vidljivi daljnjim utrostručenjem prometa i dobiti na kraju tog razdoblja.

Nastavno na to, u zadnje dvije godine, uključujući i pandemijsku godinu poslovanja, zahvaljujući ključnim upravljačkim odlukama uspostave trajne poslovne suradnje sa značajnim partnerima koji su u tom poslovnom odnosu prepoznali kvalitetu i sigurnost poslovanja, nastavlja se rast prihoda i tržišnog udjela poduzeća. To ponovo uvjetuje potrebu rasta kapaciteta pa se donosi odluka o nabavci trenutno najsuvremenije laserske opreme, upotrebom koje se već u ovoj godini očekuje rast proizvodnje i prometa za oko $50 \%$ u odnosu ne prethodno razdoblje. Prema ostvarenom prometu u prvih šest mjeseci ove godine, za očekivati je prekoračenje planiranog rasta prihoda od 42 milijuna kuna u tekućoj godini. To znači da će se, zahvaljujući recentnim upravljačkim odlukama u promatranom razdoblju, već krajem ove i početkom sljedeće poslovne godine, ostvariti vizija poduzetnika o vodećem regionalnom inovativnom servisnom centru za usluge rezanja i strojnu obradu metala, ne računajući velike proizvođače s interprodukcijom. Stoga ovaj rad daje primjer malim poduzetnicima na koji se način može, unatoč brojnim tržišnim i drugim rizicima i preprekama, zahvaljujući primjerenim praćenjima, analizama i upravljačkim odlukama osigurati uspješno poslovanje, rast i razvoj, ali je i poticaj za vlastita poslovna promišljanja i unaprjeđivanje poslovanja. 


\title{
ANATOMY OF BUSINESS SUCCESS AND BUSINESS DEVELOPMENT WITH REFERENCE TO KEY MANAGEMENT DECISIONS
}

\author{
M. Sc. Anđelko Kaščel \\ Laser Inženjering Ltd. for production and services \\ Sisačka cesta 11, 10000 Zagreb, Croatia \\ Phone: 0914222179, e-mail: andelko.kascel@laser-ing.com
}

\section{ABSTRACT}

The basic task of management in a market economy is to ensure the optimal business flow and profitability, as well as business continuity, as evidenced by the future growth and development of the company. To that end, it is essential to organize a business system that will enable timely identification of risks that can impact the company's business and business decisions. The goal of this research is to identify those risks, as well as the key managerial decisions and risk management models in given market conditions. Therefore, it is important to focus on business analysis and the development of a risk management system suited to socioeconomic changes. The research of the business success and development of a selected company encompasses the period since its founding in 2014 until the present, i.e., until the end of 2020. This seven-year period is characterized, along with constant market challenges, by a global economic recession and the most recent global pandemic caused by the COVID-19 virus, which have strongly and negatively impacted changes in the global socio-economic life both worldwide and domestically. Generally, these occurrences have negatively impacted the economy through a rise in unemployment rates, decrease in earnings, decrease in demand and production, inflation in prices, and increase in market uncertainty, particularly in the segment of small and medium enterprises. Additionally, a common entrepreneurship presumption is that the key years in the company's business and development cycle are the first, third and seventh business years, each with its own specifics, bearing its own market, economic, political and managerial risks. The selected company operated in the described economic environment, and its management made business decisions while managing business risks and development plans. That is why this document focuses on the analysis of the business and development of the selected small enterprise operating in the segment of metal-processing services, as an example of business cycles, managerial decisions ensuring business continuity, development and growth. The business was analyzed during a seven-year period, using financial and nonfinancial data and information pertaining to the period. The research was done from the aspect of analyzing exterior and interior business factors, as well as key management decisions. The management business philosophy was also taken into account. It contains, along with general managerial principles, a certain dose of specific internal managerial philosophy and principles.

Keywords: anatomy of business success, indefiniteness of business, risks business, key management decisions, specific management philosophy 


\section{LITERATURA}

1. Drucker, F. Peter: Inovacije i poduzetništvo, Globus, Zagreb,1992.

2. Grupa autora, redaktor Lajoš, Ž.: Analiza financijskih izvještaja, Masmedia, Zagreb, 2008.

3. Gulin, D., Tušek, B., Žager, L.: Poslovno planiranje, kontrola i analiza, HZRFD, Zagreb, 2004.

4. Grupa autora, redaktor Hladika, M.: Upravljačko računovodstvo, HZRFD, Zagreb, 2015.

5. Helfert E. A.: Tehnika financijske analize, HZRFD, Zagreb, 1997.

6. Horvat, Đ., Tintor, Ž.: Poduzetnička ekonomija, Trgovačka akademija, Zagreb,2006.

7. Krasulja, D.: Financijska analiza poduzeća, Ekonomski fakultet, Beograd, 1973.

8. Lapin, D.: Poslovne tajne iz Biblije, Kyrios, Zagreb, 2020.

9. Meigs \& Meigs, Računovodstvo temelj poslovnog odlučivanja, Mate, Zagreb, 1999.

10. Nickolas C. Siropolis: Menedžment malog poduzeća, Mate, Zagreb, 1995.

11. Robert N. A., James, S. R.: Računovodstvo, financijsko i upravljačko, RRIFplus, Zagreb, 2004.

12. Rodić, J.: Teorija i analiza bilansa, Ekonomika, Beograd, 1990.

13. Tintor, J.: Uvod u ekonomsku analizu poslovanja OUR-a, NN, Zagreb 1983.

14. Tintor, Ž.: Analiza financijskih izvještaja. ŠK, Zagreb, 2014.

15. Vasiljević, K.: Teorija i analiza bilansa, Savremena administracija, Beograd, 1970. 